\title{
Performance assessment of housing associations
}

\author{
Arne van Overmeeren • Vincent Gruis • Marietta Haffner
}

Received: 23 January 2008/Accepted: 28 August 2009/Published online: 21 November 2009

(C) The Author(s) 2009. This article is published with open access at Springerlink.com

\begin{abstract}
This article analyzes the function, design, and effects of a method to assess the performance of housing associations in the Netherlands. First, the roles of performance assessment are discussed from three perspectives: the association as an agent for the central government; the association as a facilitator of local stakeholders' needs; and the association as an autonomous social entrepreneur. From each of these stereotypical perspectives, we derive the approaches to and functions of performance assessment. The resulting theoretical archetypes of performance assessment are then employed to analyze the method that was in place in 2005 in the Netherlands. The performance assessment system is also analyzed using the director, detector, and effector elements drawn from cybernetic theory. Furthermore, the Dutch performance assessment method is briefly compared with the English inspection system. This provides a better understanding of the types of performance assessment. In light of the identified perspectives on housing associations, we conclude that the Dutch method performs poorly on the director and effector element and that the English method performs relatively well on all elements. Nevertheless, in both countries adjustments in the performance assessment system can increase learning and improve the performance of housing associations.
\end{abstract}

Keywords Performance assessment - Inspection · Governance · Housing associations · The Netherlands · England

This research is part of Delft Centre for Sustainable Urban Areas of TU Delft. An earlier version of this article was presented at the 2007 ENHR International Conference on Sustainable Urban Areas in Rotterdam.

A. van Overmeeren $(\bowtie) \cdot$ V. Gruis

Department of Real Estate and Housing, Faculty of Architecture, Delft University of Technology,

Delft, The Netherlands

e-mail: A.J.vanOvermeeren@tudelft.nl

V. Gruis

e-mail: V.H.Gruis@tudelft.nl

M. Haffner

OTB Research Institute for Housing, Urban and Mobility Studies, Delft University of Technology,

Delft, The Netherlands

e-mail: M.E.A.Haffner@tudelft.nl 


\section{Introduction}

In the Netherlands, 2.4 million dwellings-35 percent of the total housing stock-are classified as social rental housing. The main type of social housing provider is the housing association, of which there are 455 (Centraal Fonds Volkshuisvesting 2008). They are private non-profit organizations with a public responsibility, legally authorized as institutions operating exclusively in the interest of housing (e.g. Ouwehand and van Daalen 2002). Since the introduction of the Besluit Beheer Sociale-huursector (decree on management of social rented sector) in 1993 and the abolition of structural subsidies for new construction and renovation in 1995, housing associations operate relatively independently as part of a system in which they are supervised on the basis of general 'fields of performance'. These are the following: accommodation of target groups; preservation of the quality of dwellings and their environment; consultation of tenants; securing financial continuity; and providing housing and care arrangements. The inspectorate of the ministry responsible for housing mainly supervises compliance with laws and regulations (Ouwehand and van Daalen 2002). Financial supervision is delegated to the Centraal Fonds Volkshuisvesting (Central Housing Fund), a nondepartmental agency which advises the ministry. The ministry can intervene on the basis of its advice.

The housing associations have no shareholders who can force them to operate efficiently and there are only general public goals to be achieved. Accordingly, there is ongoing debate in the Netherlands on the performance of housing associations (e.g. Priemus 2003; Gruis 2005). Questions have been raised about the effectiveness and the efficiency of the housing associations and about how housing associations can be stimulated to improve their performance. Furthermore, there is some debate on the role of the regulatory regime in assessing the performance of housing associations (e.g. Conijn 2005). Within this debate, 'performance assessment' (visitatie in Dutch) is often mentioned as part of a possible restructuring of the regulatory framework of the housing association sector (see Brandsen and Helderman 2004; de Boer et al. 2005; Commissie Sas 2005; Conijn 2005).

Since 2002, performance assessments had been conducted on a voluntary basis. Raeflex, an independent foundation, has assessed housing associations at their own request. Thus, performance assessment had not been part of the public regulatory framework in the Netherlands.

However, since January 2007, performance assessment has been part of the Aedescode, a set of sector regulations, set up through Aedes, the national umbrella organization of housing associations. Housing associations will have to have themselves assessed once every 4 years by an independent, external, and authoritative organization. The members of Aedes have to be in compliance with this code. The performance assessment framework has been developed and managed by an independent foundation, Stichting Visitatie Woningcorporaties Nederland (Foundation Performance Assessment Housing Associations the Netherlands). It has accredited five companies to execute the performance assessment, of which Raeflex is one. These companies have, within the framework, a certain degree of freedom in how they assess the performance of housing associations. The housing association can choose which approach suits them best. The outcome of the performance assessment is publicly available.

Performance assessments have not been used for government supervision in the Netherlands, but in the near future they are expected to play a role in the public regulatory framework. In a letter to parliament, the Minister of Housing states that, given a positive performance assessment, the external supervision can be moderate. The Central Housing 
Fund will be transformed into a supervisory body, which will supervise not only the financial performance but also performance on governance, integrity, legitimacy, effectiveness, and efficiency. According to the Housing Minister, the performance assessment will be one of the sources of information used by this new supervisory body. This new body will give advice to the ministry, which can intervene when performance is not satisfactory (van der Laan 2009).

Although performance assessment is expected to play a more prominent role within the regulatory system, there is no consensus on what the function of performance assessment is, nor on how it should be implemented. The discord was even greater at the time we started our study in 2005. Some people see performance assessment as an instrument for broad public accountability (Brandsen and Helderman 2004), while others see it as an instrument for professionalizing internal governance (Schilder et al. 2006). Some argue that it is an instrument organized by the sector itself (de Boer et al. 2005), while others look upon performance assessment as an instrument of public governance (Projectgroep Wonen 2005). The different views on the function of performance assessment coincide with the perspectives on the role of the housing association. It can be seen as an instrument for delivering government policy, as a facilitator of the needs of local stakeholders, or as an independent autonomous entrepreneur with social objectives (e.g. Toonen et al. 2003; Mullins 2006).

In this article we aim to clarify the different functions of performance assessment, the different ways of designing the instrument, and the effects of performance assessment in relation to its functions, drawing on experiences in the Netherlands and England. First, we discuss three different perspectives on the housing associations and the associated function and design of performance assessment methods that (theoretically) fit within these perspectives. This discussion is couched in a cybernetic framework (e.g. Hood et al. 1999; Boyne et al. 2002) (see Fig. 1). Then, we typify the function and design of the performance assessment method in the Netherlands, employing the theoretical perspectives. After that we analyze the effects of the Raeflex method (of before January 2007) in relation to the various functions of performance assessment. Then we reflect upon the Dutch method by looking at the English inspection system that was in place in 2006. The article ends with some conclusions and considerations about the (re)design of performance assessment systems.

Fig. 1 Framework for analysis of performance assessment systems

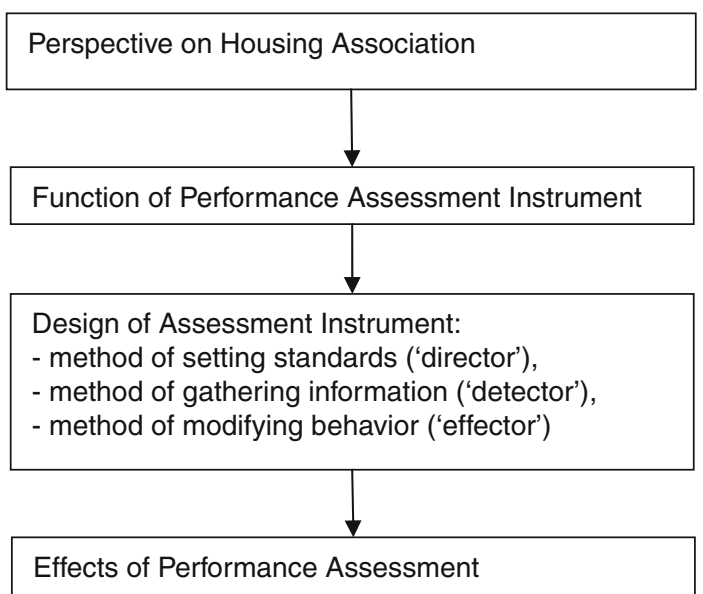




\section{Methodology}

We used different methods for the two countries. Besides doing a literature review for both countries, for the Netherlands we conducted five extensive case studies while for England we held 18 telephone interviews. However, since the empirical part of this article is focused on the Netherlands, the aim is not to compare the countries. Instead, we use the results from the interviews in the two countries to illustrate different ways of designing performance assessment methods in relation to different perspectives on the housing association. Thus, the different methodologies are not considered a barrier to interpreting the results. These results are mainly about how the interviewees think the performance assessment system works in their own contexts.

\section{Perspectives on housing associations}

Nowadays, housing associations are often regarded as social entrepreneurs (e.g. Boelhouwer 1999; van Dijk et al. 2002; Marshall and Lovatt 2004; Gruis 2005; Pawson 2006). They are organizations that by preference provide housing services to people who have difficulties in obtaining those services in the market. Yet, why do these organizations provide those services? What drives the organizations? We distinguish three theoretical perspectives on the housing association as a social entrepreneur, partly based on Toonen et al. (2003). In practice, housing associations will mostly be regarded as hybrid institutions operating from a mixture of these perspectives.

\subsection{Publicly driven social entrepreneur}

From a public administration perspective, the housing association can be seen as a means for implementing government policy. The housing association fulfils public tasks for which the government has a constitutional responsibility. For reasons of efficiency, legitimacy and social support, government may have transferred these tasks to housing associations (Toonen et al. 2003). The housing association should thus be held accountable for accomplishing the public tasks.

Seen from the angle of the social enterprise itself, Toonen et al. (2003) portray it as a private company that is commercially active in the public domain, one which is willing to undertake activities in the interest of good social services above and beyond providing basic services. Within this view we can make a further distinction between housing associations that are primarily driven by their surrounding stakeholders (stakeholder-driven social entrepreneur) and housing associations that are primarily driven by their own visions and ambitions (autonomous social entrepreneur; Haffner et al. 2005).

\subsection{Stakeholder-driven social entrepreneur}

A stakeholder-driven social entrepreneur facilitates the needs of local stakeholders. The local stakeholders are more or less in control of the housing association; they set the direction. The housing association is accountable to the stakeholders. This type of housing association can be "associated with support for community businesses and local employment initiatives” (Mullins 2006). 


\subsection{Autonomous social entrepreneur}

The housing association as an autonomous social entrepreneur chooses its own mission and goals and is only accountable to itself. The housing association determines what is best for the organization and for the clients. This type of housing association can be "associated more with an increasingly entrepreneurial orientation; a move away from a limited regulated social housing role and towards the selling of services and harnessing of assets to develop as independent social businesses" (Mullins 2006).

\section{Function and design of performance assessment system}

From various publications (Barnett 1994; Adil 1996; Ebrahim 2005; Hoek et al. 2005; Bovens 2007) we derive the following general functions of performance assessments:

- To facilitate external 'downward' supervision and control by (central) government;

- To facilitate external 'lateral' accountability towards and communication with customers and other stakeholders;

- To facilitate internal self-regulation, organizational learning and improvement.

Depending on the perspective on housing associations, some functions will be more prominent than others. As a result of the different functions, the approaches to the instrument of performance assessment can also be quite different. According to cybernetic theory there are three main elements of performance assessment methods (Hood et al. 1999; Boyne et al. 2002): director, detector and effector elements. The director element refers to the standards on which the judgments are based. The detector element is concerned with gathering information about the assessed object. The effector element is the way that housing associations' behavior is changed and performance is improved. Below, we will describe the key characteristics of performance assessment systems according to the three perspectives on housing associations, employing the distinction in director, detector and effector elements (see also Table 1). In practice, performance assessment systems can consist of a mixture of these characteristics, as will be shown in Sects. 4 and 5 .

Table 1 Characteristics of performance assessment design in relation to perspectives

\begin{tabular}{|c|c|c|c|}
\hline & $\begin{array}{l}\text { Publicly driven social } \\
\text { entrepreneur }\end{array}$ & Stakeholder-driven social entrepreneur & $\begin{array}{l}\text { Autonomous social } \\
\text { entrepreneur }\end{array}$ \\
\hline $\begin{array}{l}\text { Main } \\
\text { function }\end{array}$ & $\begin{array}{l}\text { External downward } \\
\text { supervision and control }\end{array}$ & $\begin{array}{l}\text { External lateral accountability and } \\
\text { communication }\end{array}$ & $\begin{array}{l}\text { Internal self- } \\
\text { regulation (learning } \\
\text { and improving) }\end{array}$ \\
\hline Director & Standards set by government & $\begin{array}{l}\text { Standards set according to stakeholders' } \\
\text { preferences }\end{array}$ & $\begin{array}{l}\text { Standards set by } \\
\text { management }\end{array}$ \\
\hline Detector & $\begin{array}{l}\text { Performance assessment } \\
\text { carried out by government } \\
\text { or a government agency }\end{array}$ & $\begin{array}{l}\text { Performance assessment carried out by } \\
\text { an independent body with an emphasis } \\
\text { on stakeholder consultation }\end{array}$ & $\begin{array}{l}\text { Performance } \\
\text { assessment carried } \\
\text { out by a consultancy } \\
\text { firm }\end{array}$ \\
\hline Effector & $\begin{array}{l}\text { Regulations, subsidies or } \\
\text { penalties }\end{array}$ & Stakeholders' voice and exit options & Internal drivers \\
\hline
\end{tabular}


4.1 Performance assessment from the perspective of publicly driven social entrepreneurs

In this perspective the focus of performance assessment is on the assurance that public goals are met. The public goals are set by government (director). Control and supervision are its main functions. Government carries out performance assessment and uses the results for assessing the performance of the housing association in executing public tasks (detector). If the results are unsatisfactory, the government can intervene, for example by imposing a fine or by cutting back subsidies (effector). In this perspective there is no need for a self-assessment, because the aim of performance assessment is not to improve the housing association as an organization but solely to control the accomplishment of the public goals. Besides, the internal processes will not be the main object of performance assessment.

\subsection{Performance assessment from the perspective of stakeholder-driven social entrepreneurs}

In this perspective, performance assessment is mainly an instrument for accountability to stakeholders. The social role of the social entrepreneur is emphasized. Standards regarding the achievement of social goals should be set according to stakeholders' preferences (director). An independent body should carry out performance assessment, because the report should give an unbiased picture of the housing association. In this perspective the main method is consultation of the various stakeholders by the assessors (detector). Stakeholders can use the results for judging the housing association. If they are not satisfied with the results, they can put pressure on the housing association by using their voice or, if possible, look for other housing associations (effector).

\subsection{Performance assessment from the perspective of autonomous social entrepreneurs}

In this perspective, performance assessment can be primarily seen as a tool for learning and improving performance. External relations are not taken into account unless the housing association explicitly wants to as part of its organizational learning objectives. The housing association acts on the grounds of its intrinsic mission. The focus is on the entrepreneurial side of the social entrepreneur. Standards regarding the achievement of the mission and business goals are set by the housing association (director). Performance assessment is a voluntary instrument that the housing association can choose to implement. There is no need for a general method, because performance assessment is not used for qualifying or comparing different housing associations. In this perspective the main method is staff interviews conducted by a consultancy firm (detector). The result of the performance assessment should give a good impression of the organizational performance so that improvements can be made by the management (effector). Therefore, the housing association is likely to want a comprehensive view; the aspects to be assessed would then be internal processes as well as financial and social output.

\section{Performance assessment in the Netherlands}

In 2002 Raeflex, an independent foundation, was founded specifically for assessing housing associations. Since then Raeflex has carried out just over 40 performance 
assessments at the request of housing associations. The Raeflex performance assessment (until 2007) has been used as a tool for learning and as a tool for accountability to local stakeholders. Performance assessment teams consist of a minimum of two members and a secretary. The two members are part-time assessors; at least one of them is normally working in the field of social housing (Raeflex 2003).

The function of the Raeflex system is mainly learning and improving. The housing association chooses to engage in performance assessment itself and can, but is not obliged to, apply the recommendations to improve its performance. The performance assessment, which starts with a self-assessment, not only looks at the external outcome ((social) performance) but also at the internal processes (business policy and management). Secondly, the function of accountability is significant. The public performance assessment report and the interviews with the local stakeholders both contribute to this function. The associated perspectives are those of the autonomous and the stakeholder-driven social entrepreneur.

To gain insight into the practical effects of the Raeflex system, we evaluated five Raeflex performance assessments in 2006. The evaluations consisted of an analysis of the performance assessment reports, policy documents, annual reports, and interviews with persons who were involved in the assessment. From the performance assessment reports, recommendations were derived. In the policy documents and annual reports, we looked for evidence of the implementation of those recommendations in policy or practice. In the interviews, the focus was on the reasons for performance assessment and the effects of performance assessment on the housing associations' policy. The housing associations included in our case studies were selected on the basis of having had themselves assessed in the period between May 2004 and July 2005 (date of publication of the performance assessment report). On the one hand, the Raeflex method had been developed sufficiently by then to permit a good assessment of its quality. On the other hand, the selected housing associations have had enough time since their performance assessment to at least start implementing the recommendations resulting from the assessment, so the possible impact could be determined.

The housing associations that were involved in our study have multiple reasons for choosing to engage in a performance assessment. All of them wanted to learn and improve, but they also wanted to be transparent to their stakeholders or to know what their stakeholders thought of their association. These goals fit in with the perspectives of the autonomous social entrepreneur and with that of the stakeholder-driven social entrepreneur.

As can be seen in Table 2, the majority of the recommendations were not already mentioned in the self-assessment. That could indicate that many recommendations came as a surprise. However, most respondents said that relatively few recommendations came as a surprise to them. It is hard to say if this contradiction is a result of a flawed self-assessment or a flawed performance assessment.

In most cases respondents saw the function of recommendations as one of confirmation, clarification and/or prioritization, and not as one of learning. This raises some questions about the effectiveness of the learning function of the performance assessment. If there is nothing new, what has been learned? However, if 'organizational learning' is viewed as stimulating action in response to (either new or existing) perceptions, performance assessment does seem to have learning effects.

\subsection{Director element}

Standards are mainly set by the performance assessment team itself on three subjects: business policy, management and (social) performance. Their judgments are based on their 
Table 2 Number of recommendations resulting from Dutch performance assessments

\begin{tabular}{|c|c|c|c|c|}
\hline Case & $\begin{array}{l}\text { Number of } \\
\text { recommendations } \\
\text { in performance } \\
\text { assessment report }\end{array}$ & $\begin{array}{l}\text { Number of } \\
\text { recommendations } \\
\text { already in self- } \\
\text { assessment }\end{array}$ & $\begin{array}{l}\text { Number of } \\
\text { recommendations } \\
\text { in main policy } \\
\text { document }\end{array}$ & $\begin{array}{l}\text { Examples of } \\
\text { recommendations }\end{array}$ \\
\hline 1 & 26 & 6 & 12 & $\begin{array}{l}\text { Improve transparency and } \\
\text { profile } \\
\text { Choose between two } \\
\text { strategic scenarios }\end{array}$ \\
\hline 2 & 27 & 2 & 9 & $\begin{array}{l}\text { Attention to young } \\
\text { families and starters } \\
\text { Cooperate or merge }\end{array}$ \\
\hline 3 & 21 & 9 & 7 & $\begin{array}{l}\text { More entrepreneurship } \\
\text { Transparency to stakeholders }\end{array}$ \\
\hline 4 & 12 & 9 & 11 & $\begin{array}{l}\text { Attention to internal } \\
\text { organization } \\
\text { Cherish the relationship } \\
\text { with the local authority }\end{array}$ \\
\hline 5 & 8 & 2 & 6 & $\begin{array}{l}\text { Plan policy } \\
\text { Attention to social policy } \\
\text { instead of technical quality }\end{array}$ \\
\hline
\end{tabular}

Source: van Overmeeren (2007)

own standards of how a housing association should perform and are influenced by the documents that are available and the views of the interviewees.

\subsection{Detector element}

The performance assessment team detects the performance through a self-assessment, which includes filling in a questionnaire, through policy documents and a quick scan of factual data, and through interviews with the board, the management and employees of the housing associations as well as with the board and/or management of local stakeholders such as councils, tenant organizations, care institutions and neighboring housing associations. After the interviews the performance assessment team writes the performance assessment report and presents it to the housing association. Most of the interviewed external stakeholders thought the performance assessment report gave them a good impression of the housing association.

\subsection{Effector element}

All housing associations used recommendations from the performance assessment report as input for new policy. However, not every recommendation has been taken on board in policy documents or in practice. In some cases the reason is that the housing association does not agree with the recommendation made by the performance assessment team. In other cases no explicit reason is given.

Many of the interviewed stakeholders were not satisfied with the follow-up to the performance assessment. They did not see many recommendations finding their way into 
daily practice. Most housing associations did not discuss the performance assessment and the resulting actions with their stakeholders after the performance assessment was finished.

When we evaluate the Raeflex system in light of the three elements of performance assessment methods (director, detector and effector), we conclude that the director and effector elements are quite weak and the detector element is relatively strong. Standards are ill-defined and implicit (depending on the people in the performance assessment team and the interviewed stakeholders). There is no external driver to assure that behavior is changed and that performance will be improved. The strength of the internal driver depends on the housing association as an autonomous social entrepreneur.

\section{Inspection in England}

To reflect upon the Raeflex system we looked at the English inspection system as it was in place in 2006. Although the English context differs from the Dutch, the English system is pertinent since it is designed from the perspective of publicly driven social entrepreneurs (see Table 1). It is used as part of the public regulatory regime to assess the performance of housing associations, also called Registered Social Landlords (RSLs).

The Housing Corporation, a statutory non-departmental public body that was abolished in 2009, assesses the performance of RSLs through the Housing Corporation Assessments (HCA). For this the Housing Corporation uses inspection reports about RSLs that the Housing Inspectorate, part of the Audit Commission, compiles since April 2003. The Audit Commission is a non-departmental public body that is responsible for ensuring that public money is spent economically, efficiently, and effectively. A goal of inspection is to be a 'catalyst for change'. Inspections inform the public about the performance of inspected services and contribute to policy debates (Audit Commission 2007).

To gain insight mainly into the effector element of the English inspection system, telephone interviews were held with chief executives and directors of RSLs and with representatives of the Housing Corporation, the Audit Commission, and the Tenant Participation Advisory Service. The interviews were held in two rounds. The first round consisted of a series of explorative interviews with seven respondents. From these interviews we formulated some propositions that were checked by eleven respondents in the second round of interviews. Respondents could agree or disagree with the proposition and could clarify their choice.

\subsection{Director element}

RSLs are assessed on different aspects. These aspects are described in the key lines of enquiry (KLOE). KLOEs provide criteria for assessing and measuring the effectiveness and efficiency of housing services, which form the focus of English inspections.

Many respondents thought the KLOEs are too process oriented and too prescriptive. They would prefer a set of norms based on outcome, by which the housing association decides how to get there.

\subsection{Detector element}

Every year the Audit Commission sets up an inspection program. It decides which RSLs will be inspected, taking into account policy priorities, available resources, Housing Corporation Assessments, the size and stock distribution of RSLs, their risk profile, 
Housing Corporation supervision activity, and previous inspection ratings (Housing Corporation 2005).

The inspection teams consist of professional inspectors, complemented with tenant inspection advisers and affiliate housing inspectors.

The first part of the inspection is the self-assessment, which consists of descriptions of the context, the performance on the KLOEs and the prospects for improvement, and of a summary of the action plan. Then the context analysis starts. The inspection team studies the submitted documents and the self-assessment and analyses the performance. After this analysis, there is a briefing of the RSL where the process, time path, and focus of inspection are discussed. Subsequently, the fieldwork begins. At the end of the fieldwork, the inspection team will give general feedback to the inspected RSL. The draft report will be presented, to which the RSL can respond. After that, the inspection team will write the final report.

\subsection{Effector element}

The inspection report results in two judgments: one about the quality of service and one about the prospects for improvements. The judgment about the quality of service can be zero to three stars; the one about the prospects for improvements can be poor, uncertain, promising, or excellent. If an RSL gets no stars, it will be re-inspected within 12 to 18 months. If an RSL gets zero to two stars the RSL is obliged to make an action plan that addresses all the recommendations in the report. The Housing Corporation monitors the delivery of the actions. At the end of the monitoring, if all recommendations are implemented, the Housing Corporation and the Audit Commission will confirm the formal completion of the action plan, which is the end of the inspection process. If the RSL fails to implement the recommendations of the action plan, or if performance and continuous improvement have not improved, the Housing Corporation can take supervision action.

Respondents from our interviews generally agreed that since the introduction of the inspection system there has been a positive effect on the performance of RSLs regarding the service delivery to tenants. As a result of the focus of the inspection system on service delivery, RSLs pay more attention to service delivery to tenants. Respondents argued that the effect is bigger on the worse performers than on the better performers. This seems to be a result of the intensive monitoring of the improvement activities. A cost-benefit analysis of the recommendations ensures that the effort of implementing a recommendation is in balance with the result of the implementation. The threat of sanctions from the Housing Corporation guarantees implementation of the recommendations. For better performing RSLs the preparation for inspection seems to be a key factor of the system. Respondents see the self-assessment as very valuable. By preparing for the inspection, improvements are already made before inspection has taken place.

If we evaluate the inspection system against the three elements of performance assessment methods (director, detector and effector), we conclude that all three elements are quite strong. But because of the prescriptive and detailed KLOEs, instead of norms set for outcomes to be achieved, the director element is valued as negative by our respondents.

\section{Conclusion}

In this article we have analyzed two methods for assessing the performance of housing associations: the Raeflex performance assessment in the Netherlands and the Audit 
Commission inspection in England. We developed a framework of three different perspectives on the tasks of the housing association and the role, design and effectiveness of systems for performance assessment. The framework was based on the assumption that ideally the design of a performance assessment system originates from the function of the system and the function originates from the perspective on the role of housing associations. Furthermore the design should contain a method to set standards (director), a method to gather information (detector), and a method to modify behavior (effector).

The Dutch Raeflex system mainly has the function of learning and improving and can be associated primarily with the perspective on housing associations as autonomous social entrepreneurs. It also emphasizes stakeholders' opinions and accountability in the performance assessment, which can be associated with the perspective of housing associations as agents of local stakeholders. The director and effector element are quite weak and the detector element is relatively strong from the perspective of the autonomous social entrepreneur.

The English inspection system emphasizes public accountability and can be associated primarily with a perspective on housing associations as agents of the government. All three elements of inspection are quite strong, but because of the detailed and prescriptive KLOEs our respondents consider the director element as negative.

From both systems lessons can be learned. Below we discuss some ideas for the (re)design of performance assessment systems, based on benefits and shortcomings of both systems.

\subsection{Consistency versus flexibility of performance assessments}

In the Dutch cases, we found differences in the structure and content of the performance assessment reports.

Some reports made very detailed recommendations, others did not. Some reports made a distinction between major and minor recommendations, others did not. There did not seem to be a clear standard of presenting and formulating the recommendations. If those differences match the particular needs of the housing associations, these differences may be deemed to contribute to the flexibility of the performance assessment system. However, if those differences are related to an ambiguity of standards (director element), or to the difference in gathering information by the performance assessment teams (detector element), these could be problematic. One way to deal with inconsistencies is to systematize the process, but this might affect the possibility to provide tailor-made recommendations. In England, for example, many respondents thought the KLOEs are too process oriented and too prescriptive. They would prefer a set of norms based on outcome, by which the housing association decides how to get there. Unfortunately, such norms are also absent in the Dutch system.

To combine the flexibility of the Raeflex performance assessments with the relatively consistent approach of the Audit Commission, the performance assessment teams could be composed of full-time professional assessors combined with part-time peers. The experience and systematic approach of the professional assessors would then be combined with the open minds of the part-time peers for achieving a consistent judgment while appreciating differences in context and approach. Nevertheless, in England, where the inspection process is relatively well defined, the consistency of inspections was an issue as well. The interviewees related the inconsistencies to the quality of the inspection teams. Some respondents found that the inspection teams were consistent, others found that they were not. Thus, it is unrealistic to expect that performance assessments can be made fully consistent in practice. 


\subsection{Embedding and follow-up of the performance assessment results}

In the Dutch cases we found that after the performance assessment was finished, there was not always a clear picture of what to do with the results and how to embed them in the organizational processes (effector element). If performance assessment is seen as an instrument for accountability to stakeholders, handing out an performance assessment report to stakeholders is not enough. Part of accountability is the dialogue between the housing association and its stakeholders. Stakeholders should be able to give their opinions about the resulting report and ask for explanations of particular findings of the performance assessment team. If an objective of performance assessment is to learn and improve, the performance assessment should not only result in recommendations but also include some guarantee that the recommendations are implemented and that improvements are being made.

There are several possibilities to improve the follow-up:

- Housing associations could consider being more explicit about what they are going to do with the performance assessment results. They could, for example, refer to the performance assessment in their annual reports and in their business plans.

- In the English system the obligation to make an action plan and monitor it serves as a guarantee that the recommendations are being implemented and that improvements are being made. Another possibility is to use the performance assessment results as a kind of supervision agenda for the board.

- In between two performance assessments, housing associations could consider having a sort of midterm review. This review should be focused on the implementation of the recommendations (learning and improving) and could be a light version of the performance assessment. The real performance assessment can then act more as an instrument for accountability to stakeholders.

\subsection{Added value of framework}

The framework we designed to analyze two performance assessment systems of housing associations in the Netherlands and England takes into account both the three cybernetic elements of control as well as three perspectives on the housing association as a social entrepreneur. By connecting the three perspectives with the cybernetic elements, we have constructed a framework with which it will also be possible to analyze other performance assessment systems in other countries and of other types of social entrepreneurs.

Acknowledgments We wish to thank the Central Housing Fund (CFV) for its financial assistance of the research on the Dutch performance assessment system and Aedes, the Dutch association of housing associations, for commissioning a report on the English inspection system. Furthermore, we would like to thank all interviewees who have helped us to collect our material.

Open Access This article is distributed under the terms of the Creative Commons Attribution Noncommercial License which permits any noncommercial use, distribution, and reproduction in any medium, provided the original author(s) and source are credited.

\section{References}

Adil, N. (1996). NGO accountability: A conceptual framework. Development Policy Review, 14(4), 339-354. Audit Commission. (2007). About inspection [online]. From http://www.auditcommission.gov.uk/housing/ about.asp?CategoryID=english $\% 5 \mathrm{E} 1628$. 
Barnett, R. (1994). Power, enlightenment and quality evaluation. European Journal of Education, 29(2), $165-179$.

Boelhouwer, P. (1999). International comparison of social housing management in Western Europe. Journal of Housing and the Built Environment, 14(3), 225-240.

Bovens, M. (2007). Analysing and assessing accountability: A conceptual framework. European Law Journal, 13(4), 447-468.

Boyne, G., Day, P., \& Walker, R. (2002). The evaluation of public service inspection: A theoretical framework. Urban Studies, 39(7), 1197-1212.

Brandsen, T., \& Helderman, J. K. (2004). Volkshuisvesting. In H. Dijstelbloem, P. L. Meurs, \& E. K. Schrijvers (Eds.), Maatschappelijke dienstverlening: een onderzoek naar vijf sectoren. Amsterdam: Wetenschappelijke raad voor het regeringsbeleid/Amsterdam University Press.

Centraal Fonds Volkshuisvesting. (2008). Verslag financieel toezicht woningcorporaties 2008. Naarden: Centraal Fonds Volkshuisvesting.

Commissie Sas. (2005). Corporaties lokaal verbinden; presteren en verbinding zoeken zondervrijblijvendheid. Hilversum: Aedes.

Conijn, J. (2005). Woningcorporaties: naar een duidelijke taakafbakening en een heldere sturing. Amsterdam: RIGO Research en Advies BV.

de Boer, H., Hooge, E., Biesheuvel, P. J., Meurs, P., van Leeuwen, L., \& Lensen, T. (2005). Lokaal wat kan, centraal wat moet Nieuw bestel voor woningcorporaties. Hilversum: Aedes/VROM.

Ebrahim, A. (2005). Accountability myopia: Losing sight of organizational learning. Nonprofit and Voluntary Sector Quarterly, 34(1), 56-87.

Gruis, V. (2005). Financial and social returns in housing asset management: Theory and Dutch Housing Associations' practice. Urban Studies, 42(10), 1771-1794.

Haffner, M., Elsinga, M., \& Wolters, A. (2005). Het stedelijk vernieuwingsnetwerk. Verkenning in theorie en praktijk. Gouda: Habiforum.

Hoek, F., van Montfort, C., \& Vermeer, C. (2005). Enhancing public accountability in the Netherlands. OECD Journal on Budgeting, 5(2), 69-86.

Hood, C., Rothstein, H., Baldwin, R., Rees, J., \& Spackman, M. (1999). Where risk society meets the regulatory state: Exploring variations in risk regulation regimes. Risk Management, 1(1), 21-34.

Housing Corporation. (2005). How we regulate 5: Viability. London: Housing Corporation.

Marshall, D., \& Lovatt, R. (2004 April). Valuing social enterprise in the social housing sector. Paper presented at the housing studies association spring conference, Sheffield Hallam University.

Mullins, D. (2006). Exploring Change in the Housing Association Sector in England Using the Delphi Method. Housing Studies, 21, 227-251.

Ouwehand, A., \& van Daalen, G. (2002). Dutch housing associations. A model for social housing. Delft: DUP Satellite.

Pawson, H. (2006). Restructuring England's social housing sector since 1989: Undermining or underpinning the fundamentals of public housing? Housing Studies, 21, 767-783.

Priemus, H. (2003). Social housing management: Concerns about effectiveness and efficiency in the Netherlands. Journal of Housing and the Built Environment, 18(3), 269-279.

Projectgroep Wonen. (2005). Goed wonen: voor iedereen, van iedereen. Amsterdam: PVDA.

Raeflex. (2003). Protocol visitatie, versie 03-2003-01. Hilversum: Raeflex.

Schilder, A., Mosch, R. H. J., \& Hage, M. (2006). Advies toezicht op woningcorporaties. Amsterdam: De Nederlandsche Bank.

Toonen, T., Dijkstra, G., \& van der Meer, F. (2003). De waarde van de maatschappelijke onderneming geborgd. Hilversum: Netwerk Toekomst Maatschappelijke Onderneming.

van der Laan, E. E. (2009). Voorstellen woningcorporatiestelsel. Ministerie voor Wonen Wijken en Integratie: 's-Gravenhage.

van Dijk, G., Klep, L. F. M., van der Maden, R., Duit, I. G. A., \& van Boekel, P. (2002). De woningcorporatie als moderne maatschappelijke onderneming. Assen: Koninklijke Van Gorcum.

van Overmeeren, A. J. (2007). Visitatie van woningcorporaties. Delft: TU Delft. 